Information for citation:

Finogentova O. E., Tokarev V.A. Zarozhdenie sotsiologicheskoy teorii prava v SSSR [The Emergence of the Sociological Theory of Law in the USSR]. Vestnik Permskogo Universiteta. Juridicheskie Nauki - Perm University Herald. Juridical Sciences. 2017. Issue 35. Pp. 16-32. (In Russ.). DOI: 10.17072/1995-4190-2017-35-16-32.

UDC 340.13

DOI: 10.17072/1995-4190-2017-35-16-32

\title{
THE EMERGENCE OF THE SOCIOLOGICAL THEORY OF LAW IN THE USSR
}

\section{O. E. Finogentova}

Immanuel Kant Baltic Federal University

14, A. Nevskogo st., Kaliningrad, 236016, Russia

ORCID: 0000-0001-5281-5517

ResearcherID: Q-8256-2016

e-mail: finogentovaoe@mail.ru

\section{A. Tokarev}

Samara State Regional Academy (Nayanova)

196, Molodogvardeiskaya st., Samara, 443001, Russia

ORCID: 0000-0003-4568-9764

ResearcherID: S-4989-2016

e-mail: basiletok@gmail.com

Introduction: the article is devoted to the analysis of the genesis of the Soviet theory of law, in particular, of the sociological concept of law by P. Stuchka. In this regard, the relation of jurisprudence with other social sciences, such as philosophy, political science and sociology, acquires particular importance. Special attention is paid to the attempts of reconciliation of Marx's concept of withering away of the state and the law in a communist society with the realities of the young Soviet state. Purpose: to form a concept of prerequisites and peculiarities of formation of Russian legal theory in the 1920-30s. Methods: theoretical methods of formal and dialectic logic have been applied. Results: the analysis shows that in their attempt to reconcile Marxist theory with the reality and inner logic of the law the Soviet jurists relied on the achievements of pre-revolutionary Russian legal theory, primarily a sociological theory of law. In addition, the relative epistemic pluralism of social sciences in the first decades of the Soviet regime allowed them to elaborate original concepts, for example, the concept of codification. Conclusions: the Soviet theory of law in its early stages faced the problems of determining the essence and the content of law, and of the relationship between the law, state and society of a new type. The problems were caused by the dominant ideology of Marxism-Leninism and epistemological obstacles in legal knowledge. The attempts to solve these problems undertaken by the Soviet jurists are of great interest to modern legal theorists who are in search for appropriate methods of legal research.

Keywords: legal epistemology; Marxism; legal reality; natural law; positivism; sociological theory of law; revolutionary law; dictatorship of the proletariat

C Finogentova O. E., Tokarev V. A., 2017 


\section{Information in Russian}

\section{ЗАРОЖДЕНИЕ СОЦИОЛОГИЧЕСКОЙ ТЕОРИИ ПРАВА В СССР}

\section{О. Е. Финогентова}

Доктор юридических наук, профессор кафедры теории и истории государства и права Балтийский федеральный университет им. Иммануила Канта 236016, Россия, г. Калининград, ул. А. Невского, 14

ORCID: 0000-0003-4568-9764

ResearcherID: Q-8256-2016

e-mail: finogentovaoe@mail.ru

\section{B. А. Токарев}

Кандидат юридических наук, зав. кафедрой истории государства и права Самарская государственная областная академия (Наяновой) 443001, Россия, г. Самара, ул. Молодогвардейская, 196

ORCID: 0000-0001-5281-5517

ResearcherID: S-4989-2016

e-mail: basiletok@gmail.com

Введение: статья посвящена исследованию генезиса советской науки теории права, в частности анализу соичологической конщепчии права П. И. Стучки. В связи с этим вопросы взаимосвязи правоведения с другими общественными науками - философией, политологией, соииологией приобретают особое значение. Отдельное внимание уделяется попыткам примирения основополагающего тезиса марксизма об отмирании государства и права в коммунистическом обществе с реалиями молодого советского государства. Цель: сформировать представление о предпосылках и особенностях формирования отечественной юридической науки в 20-30-е г2. ХХ в. на основе анализа основных проблем, поставленных и решаемых ведущими советскими юристами. Методы: теоретические методы формальной и диалектической логики. Результаты: анализ показал, что в своем стремлении примирить положения марксисткой философии с реальностью и внутренней логикой права советские юристы опирались на достижения отечественной дореволюичионной науки, прежде всего соииологического направления в правоведении. Кроме того, характерный для первого десятилетия Советской власти относительный эпистемологический плюрализм в общественных науках позволил им разрабатывать оригинальные конщепции, например, кодификации. Выводы: советская наука теории права на этапе своего становления столкнулась с проблемами определения сущцости и содержания права, специфики его взаимоотномений с государством и обществом нового типа, которые были обусловлены как господствующей идеологией марксизма-ленинизма, так и характерными для юриспруденичи эпистемологическими препятствиями к познанию права. Попытки решения этих проблем, предпринятые советскими учеными, представляют несомненный интерес для современных теоретиков права в перспективе поиска адекватной методологии правовых исследований.

Ключевые слова; юридическая эпистемология; марксизм; правовая реальность; естественное право; позитивизм; социологическая теория права; революционное право; диктатура пролетариата

\section{Introduction}

Contemporary representatives of legal epistemology point at three impediments faced by jurists in studying law. The first one is a false clarity of subject matter that turns into misconception, when under the slogan of direct recourse to legal experience between the legal reality and scientist is being set a kind of screen of concepts and categories which, finally, become a true object of study. The second impediment is that legal science, being formed in such a way, functions as a social life revealing, not explaining or even describing it, but representing a defined model of relationship through categories and concepts in a particular so- ciety. At the same time, in fact, this model seems to be not only abstract due to the nature of instruments it is created, but also idealistic, because it bears the impress of certain ideology. Finally, separate studying and also teaching branches of jurisprudence at law departments lead to a gap between them and other sciences, which lawyers attempt by the socalled "interdisciplinary approach" [36, pp. 37-68].

Reasons why lawyers make sure of their subject matter clarity are not hard to plumb. Positivism, which took a strong position in the 19th century and then developed in different variations (especially rapidly in our country for a variety of reasons), extols the experience as a reliable 
reference point in understanding the legal reality. Moreover, legal knowledge in the sight of positivists is nothing short of quintessence of legal experience gained in the society. Actually, the direct legal experience in their research is replaced by metaphysical mediation or as Karl Marx, who criticizes Hegel's legal philosophy, puts it - "logical, pantheistic mysticism" [13, vol. 1, p. 224]. As a result of this, categories and concepts become a separate entity putting on the back burner real legal entities. Getting involved in this game, the jurist risks to forget that concepts and categories are secondary, because they serve the cognitive process as accessorial instruments, whereas the primary focus is on the legal reality in which a juridical entity tries to find responses for questions about the freedom and justice. Meanwhile, if the legal reality does not fit the "Procrustean bed" of legal science, positivists try to make it fit a pre-existing framework that given a priori, chief among which is the postulate of justice universalism. It is a magic word - "justice" - admits variety of use cases without any time or space limitation. Thus, during the period of the New Economic Policy (NEP) Soviet jurists tried to bring together fundamental principals teachings of Karl Marx and Frederich Engels about justice and state with the social, economic and political realities of the first post-revolutionary decade by offering them new, adequate terminology. According to the known British historian of political and legal doctrines John Kelly, who analyzes that era, "The official theory used for explaining this perpetuation of bourgeois forms was that the new legal order was indeed the expression of the interest of the dominant class; but this, of course, was now the proletariat. And this legal order would be operated in the light of that class's overriding objectives and destiny. This general position was stated as early as 1921 by the People's Commissar for Justice in the first revolutionary government, lawyer Peter Stuchka (1865-1932); he summarized it in 1928 in a formula stating that Soviet law maintained by the state during the period of transition was bourgeois law minus the bourgeoisie" [32, p. 372].

The model of legal reality proposed by positivists is a set of judgments about it, interrelated and subject to rules of their statement and evaluation.
Rules of juridical discourse formation turn out to be more meaningful for a positivist than the actual set of legal norms, as legal reality can be subjected to the idea of it through universal concepts and categories of legal science. Researches of positivists focus on signs of presence of a particular law in social life, then on the law itself, or more precisely, on rules of law, but almost never lay emphasis on law as a system. It is enough to see that the law exists and its force is unpreventable, and the juridical science services as a constant reminder of this. Science should not simply explain, but justify the existence of law and the particular form of the state. Legislation and juridical science impose a particular model of legal reality on the subject. As foreign lawyers note, when a legal process begins, the subject undergoes symbolic violence in accordance with current legislation and dominant ideas of law and state, which becomes real in the course of time [26, p. 142].

The role and influence of a particular legal conception on the public life are weakened or strengthened, also concepts can displace each other (for example, natural law doctrines were displaced by legal positivism in the second half of the 19th century - first half of the 20th century), but fundamental principles are kept and put into practice under appropriate conditions. However, one must remember that attempts to implement political and legal doctrines, as a rule, do not bring the results their creators expected. The future of Marxian doctrine of law and state in Soviet Russia was not an exception. This article focuses on the analysis of problems associated with comprehension and transformation of the domestic legal doctrine of 1920s-1930s, first of all, by Peter Stuchka. It consists of three parts, in which are considered features of Marxian approach to the essence of the state and law, the post-revolutionary concept of the state and law, as well as the historical background for development of sociological theory of law in the USSR.

\section{The Marxian Approach to the Definition of the Essence of the State and Law}

The cornerstone of Marxist theory of communist society is the concept of the withering away of such social institutions as 
state and law. The need for them will disappear as soon as the class division of society is gone. At the same time, one of Marx's biographers notes, "The promise of lack of law", leading to a "perfect justice", was correctly interpreted by Hans Kelsen as "utopian prediction" [34, p. 78]. Since each type of state corresponds to a particular type of law, the latter, generally understood by Marx and Engels as a historically transient phenomenon in which society is only interested at a certain stage of its development, will just wither away with withering away of the state. Marxism does not leave a place for the law in the future communist society, where, as the French jurist Francois Terre said, "The disappearance of law follows withering away of the state" [38, p. 155].

It should be emphasized that Marxism did not define and research the problem of the essence of law beyond its socio-economic nature. According to Marx and Engels, law is a part of a superstructure over the economic basis and it is of a minor, derivative character. As the Australian law professor Augusto Zimmerman notes, "Marx considered that there can be nothing intrinsically good in the existence of law. Arising from the conflict between social classes as the need to control such a conflict, positive laws would cease to exist with the final advent of communism" [42, p. 20]. According to Augusto Zimmerman, Marxism describes and explains legal reality limiting it by certain economic relations, using concepts and categories of the class struggle, formation and economic determination of social phenomena. In general, exaggeration of the role of the class beginning in the process of law formation and development is a characteristic feature of Marxism. According to its theorists, class contradictions act as a "firing trigger" in case of law aborning and a catalyst of social progress on the whole. The deterministic approach of Marxists to understanding features of society development and its structural elements actually prevented evolution of social mechanisms that were aimed at improving legal norms and juridical tools.

For example, professor Sergey Alekseev makes an interesting comparison between natural and legal ideas and the Marxist legal philosophy. According to him, despite contradictions between them and apparent lack of common denominator, the central concept in Marxist philosophy becomes a new ver- sion of "natural right" - "a revolutionary right, some kind of super right of the proletariat to fundamental world remaking". What is more, Marxists comprehend law not in the strict legal sense and not even in the sense of the right of power, but in a broad sense i.e. as "validity, propriety" of certain actions that have "valid cause" [2, p. 480]. The Marxist "natural law" has an incontestable primacy over positive law and so legitimates abuses of it. Let us note that foreign experts in history of legal thought of the Soviet period also agree with Sergey Alekseev's opinion. For example, Fr. J. Goman notes, when analyzing Peter Stuchka's conception of law in the article "Soviet Theory of Law" (1965), "He thought that there was "natural law" growing out of social intercourse. This "natural law" had precedence over "artificial law" consisting of statutes and governmental decrees" [31, p. 405].

Practical implementation of the Marxist doctrine about law and state led to violation of legal norms and establishment of dictatorship, whereas its essence - withering away of law and state - was changed. The period of Lenin's leaderism was characterized by a certain romantic attitude, high communistic ideals, while the period of Stalin's regime was connected with creation of the totalitarian government system, in which the personality, contrary to Karl Marx's expectations (as they were expressed, for example, in the article "On the Jewish Question" [13, vol. 1, p. 406]), did not gain allround development, being only a small screw in the huge state machinery. In the Soviet state took place a deviation from one of the basic provisions of Marxist legal philosophy, namely extolling the state's role, bringing it to the absolute. On the contrary, according to the basic provisions of Marxism, the "semi-state", which was planned only for a transition period, did not assume availability of either permanent administrative machinery or regular army. Amendments were also made in the idea about withering away of law. Vladimir Lenin claimed: "Without falling into utopianism, it is impossible to think that, having overthrown capitalism, people learn right away to work for society without any rules of law; besides, cancellation of capitalism does not provide any economic prerequisites for such change straight away" [12, vol. 33, p. 95].

Considering law under socialism as a temporary phenomenon, whose existence in society was 
caused by a number of objective circumstances, he meant bourgeois law. In his opinion, "in the early phase of communist society (which is usually named socialism) the bourgeois law is cancelled not completely, but only partially, exclusively in relation to capital goods" [12, vol. 33, p. 94].

The place and role of the law, public order and judicial system in the state of the "proletarian dictatorship" under construction relied on Lenin's doctrine about the state and class struggle, which legitimated the establishment of the political domination of the proletariat in the form of its dictatorship, i.e. the power based directly on the armed force of masses and not being shared with anybody else. Insofar as the proletariat was the unique legitimate power holder, its dictatorship could not be limited by the formal law, and the use of violence was legitimate and necessary. This provision became the key, once and for all determining the Bolsheviks' relation not only to the system of power on the whole but also to its core components - to the right and the law. As Francois Borella notes concerning the legal nature of the proletarian dictatorship, "The single party, avant-garde party and its leader deal with an unresolvable question of liberal democracy: do people manage itself when the majority actually controls them? The answer is obvious: the people are this party and its leader" [23, p. 109].

Another fundamental provision of the Bolshevik law conception is interdetermination of law, state power and policy. In the view of the foreign legal ideology expert Paul Hirst, "Socialism means nothing when it is not the legal ideology: a discourse that directs policy to creation of certain forms of social relations in certain ways; a discourse that can create and assess political situations (in context of definite purposes)" [30, p. 8]. The classical idea gained new content in Lenin's interpretation because the right and the law gained official recognition as the tool of the state policy. In 1916 Vladimir Lenin wrote in the article "A Caricature of Marxism and Imperialist Economism" that the law is a political aspect and also a policy [12, vol. 30, p. 99]. Indeed, policy has been and remains a component of the state lawmaking activities, and laws are its concentrated term, but in the context of "policy - law", from the Bolsheviks leader's point of view, policy prevails over the law, therefore the latter becomes a back-up tool of policy. In fact, he does not acknowledge law as possessing independence and internal logic, substituting them for political expediency. The reason for such attitude toward the law was given by authors of "Manifesto of the Communist Party" themselves. As is emphasized by the British professor Hugh Collins, since the destiny of humankind was considered to lie in the emergency of lawless communism, law was interpreted as not encompassing any universal values or principles, but rather representing a transitional device that merely illustrates "the course of political struggles and the evolution of social formations" $[25$, p. 9].

Thus, the essence of the matter lies in merging of Marx's ideas about the state and law, about communist society with the etatism policy, but not in change of reference points and exaggeration of the role and value of the state. In other words, there was no substitution of Marxist legal philosophy for the state ideology glorifying the power but etatism of utopian philosophy of communism. It led to creation of a specific system of "double-level law" (Sergei Alekseev), in particular, to coexistence of positive law, which contained provisions quite progressive for that time, and "revolutionary law" with higher priority.

The Soviet Constitutions, providing personal rights and ensuring their observance, thereby were creating the illusion of the legal, but in practice these norms were not implemented. "On the contrary, others aspire, following Karl Marx's thought, to the temporary establishment of dictatorship of the proletariat in order to reach the communist society, in which freedom, equality and real democracy would be guaranteed. Their purpose is democratic, as opposed to the proletarian dictatorship", - the French lawyer Marie-Anne Cohendet notes [24, p. 151]. The declared principle of socialist legality was the chimera covering arbitrariness and violence. As Sergei Alekseev notes, the concept of "revolutionary law" means "something more than just consciousness and represents something like revolutionary natural law", although it is closer to the concept of "legal consciousness", i.e. to personnel subjective perceptions of "the real, desirable and admissible law". "Revolutionary law" is actually beyond the concept of "legal consciousness" because it allows for "something that positive law systems do not 
allow, as well as does not any consciousness containing the category of "law" in its strictly legal meaning - direct, uncontrollable, boundless and mass violence" [2, pp. 482-483]. The impossibility to implement in practice progressive principles and norms of Soviet law is related to the fact that the leading element of the current legal system proved the so-called "revolutionary law", which gave free rein by positive law to the leader and party nomenclature to act at their own discretion.

Positive law was necessary for the Bolsheviks to justify their decisions and undertaken activities, so it performed rather a decorative role. Thus, according to Alexandr Goykhbarg, "It would be a good thing to rise out the word "law" if we could replace it with another one" [4, p. 4]. However, the replacement of positive law with revolutionary law was implemented, and as a result Soviet law constituted a legal system with "revolutionary law" as its dominating principle. However, it lacked an adequate understanding, which resulted in emergence of a number of original legal concepts in the first decade of the Soviet power. The famous French law theorist and historian of politico-juridical doctrines Michel Villey wrote in the mid-1960s about what had happened to the Marx's "state and law" doctrine: "It is necessary to agree with the Marxists that in our legal philosophy insufficient attention is paid to Marx's doctrine. We raise a lot of noise around a particular school exercise applying popular philosophical concepts to the law, which are just variations on the same theme, whereas the revolutionary force, which Marx tried to give our legal thought, still remains little-studied" [39, p. 329].

\section{Post-Revolutionary Legal Concepts}

To begin with, all of post-revolutionary concepts of law relied on Lenin's postulate about the impossibility to change the world and build communist society without violence. From this idea follows: the necessity of theoretical justification of the proletarian dictatorship, the search for possible forms of law accommodation in the Soviet reality, the negation of law objective nature and meaning, as well as the rationale for the temporary nature of law under socialism. Such narrow bounds, of course, did not allow the Soviet legal science to move beyond the Marxist foundations and the theory of revolutionary violence, making it impossible to establish any consistent concept of law, free from ideology of class struggle. Reduction of law cognition to law negation would lead to serious negative implications, the most important of which would be the legal nihilism, which quickly formed in the Soviet society. Directed against bourgeois law at first, it also extended to socialist law, which the Soviet lawyers gave a secondary role in management of society and state. At the same time, extra legal mechanisms of coercion were supposed to become the main methods of public administration.

Therefore, the Soviet ideologues aspired to change existing ideas about law in the domestic pre-revolutionary science, abandoning the classical concepts of the essence of law, more precisely, focusing on the role of the state compulsion in the mechanism of legal regulation of social relations. The well-known party and government leader Nicolai Bukharin considered that coercion must be transferred to "working people and the ruling class itself, because it still bears the stamp of the commodity-capitalist system" [3, pp. 140-141]. In his opinion, only proletarian coercion in the form of "shootings and labor duties" was the effective method that would allow for producing the communist society "from the materials of the capitalist era" [3, p. 146]. The legal violence was declared to be a basic method of the new social system formation.

After the revolution, law was declared by half of the Soviet Marxists an empty, illusory ideological form. For example, the People's Law Commissar of the Russian Soviet Federative Socialist Republic (RSFSR), Procurator of the RSFSR - Dmitriy Kursky claimed the abolition of old law on the ground that "abolition of all norms of bourgeois law is a sole guarantee of justice for urban and agri-proletariat and the poorest peasants" [11, p. 38]. According to Mechislav Kozlowsky, "the revolution creates a special, unprecedented law - proletarian law, which is still law, but in the sense of its being an instrument of suppression for minority opposition by working classes" [8, p. 24]. Finally, Nicolai Krylenko admitted coercion, 
if exercised by the state, as an exploitation; for this reason he considered that both Soviet law and bourgeois law were exploitative. Therefore, he concluded that one of the tasks of socialist construction should be winding down of the legal form of the Soviet state [10, p. 33].

During the first years of the Soviet system, fight against the legal world-view as a remnant of bourgeois ideology becomes the central idea of Soviet jurists. For example, Vladimir Adoratsky claims that legal thinking is unscientific, and law and state don not represent independent entities because "these ideas are only links in a chain of the process of public life. The phenomenon itself, which lurks under this idea, under this appearance, is power, armed force" [1, p. 32]. The graduate of the Law Faculty of St. Petersburg University and ex-privatdocent in the Civil Law Department Alexander Goykhbarg emphasizes, "Any conscious proletarian knows ... that religion is opium for the people. But it is rare who ... realizes that law is even more poisoning and stupefying opium for the same people" [4, p. 3]. According to professor of the Petrograd University Michael Reysner, "if law is not "opium for the people", then, in any case, it is quite dangerous medicine" [17, pp. 35-36].

Soviet jurists needed to bring into compliance the theoretical construction of classics of Marxism about the role of law in the future state structure and the practice of socialist construction. However, the first months of the Soviet state existence clearly disproved this idea. It was impossible to return life of society into the normal track, especially, to construct a new social structure without rules of law. Facing serious problems in the Soviet state creation and realizing that these can only be solved through the establishment of effective legal regulators, they understand the fallacy of Marx's idea about withering away of the law and the state in the early stage of the communist society formation, its contradiction to the logic of society development.

On the grounds of political expediency and the necessity to deal with the difficulties arising in the course of the state building due to the anarchism and lack of organization, they make a conclusion that in the early phase of communist society the "bourgeois law" is to be nullified only partially. In its other part law remains the regulator of products and labor distribution among the members of society. This particular idea will further lead to the emergence of the proletarian law concept, which will be perceived as the only allowed instrument to achieve the dictatorship of the proletariat, "at the same time accepted by and subordinated to the Party's policy" [33, p. 142]. This concept will serve as a methodological basis for the incipient Soviet jurisprudence and legal ideology.

For the French legal sociologist Jean Carbonnier, "Marxism came to some legal optimism, to recognition of the necessary to preserve law, at least as a form. Thus, from Marxism were excluded the provisions that lawyers and also sociologists of law who came out of the legal environment were repelled by" [7, pp. 125-126]. However, the methodological monopolism and cruel ideological control existed in the Soviet science for a long time, which resulted in the development of competing areas of law and even liquidation of their representatives. In the mid-1930s, various forms of symbolic violence, which kept within scientific discussions concerning legal theorists, will be replaced by real violence.

Nevertheless, in the history of Soviet law there was a period of an open scientific discussion, when questions of understanding of the role and place of law in society were decided in the course of scientific disputes. This period falls on the years of the Soviet government formation (1920$30 \mathrm{~s}$ ), which are characterized by the coexistence of several various directions of legal consciousness relying on schools of law which had developed in the pre-revolutionary jurisprudence. For example, Michael Reisner, Jakub Magaziner, Evgeni Engel, Ilya Ilyinsky in their works developed ideas of the psychological school of law, whose founder was Lev Petrazhitsky. The positivist direction of law actively developed by such scientists as Nicolai Krylenko, Mechislav Kozlowsky Sergei Kotlyarevsky, Edward Pontovich, Vsevolod Durdenevsky, Leo Uspencky and others. Sociological school of law, at the origins of which stood Nicolai Korkunov, Maxim Kovalevsky, Sergei Muromtsev, was followed by Peter Stuchka, Evgeni Pashukanis, Alfred Stalgevich, Alexander Goyhbarg, Jacob Kantorovich, Samuel Asknaziy. It should be noted that the sociologic school of legal science initially received the official support from the highest bodies of the Soviet power, and ideas of 
its followers were embodied into such an important document as "The Guiding Principles of the Criminal Law in the RSFSR" of December 12, 1919.

However, in spite of the variety of legal concepts, theories and schools, they had a common ground - denial of the objective nature and sense of the law, its essence and underlying logic, as well as justification of the proletarian dictatorship. As Ilya Ilyinsky claimed, "Law and legalism are slightly dated slogans in the era of the dictatorship of the proletariat" $[6$, p. 16]. Instead of law, it was proposed to rely on the "revolutionary legal consciousness", "revolutionary legality", "rights of the working and exploited people", non-legal regulators of people's behavior - technical standards, organizational rules and others, which, in the opinion of the Soviet jurists, matched "the highest ideals of communism" and "aspirations of people and workers".

Gradually, the initial idea of "proletarian law", as law of an essentially new, highest type, distinct from all the types that existed earlier, transforms to the doctrine of socialist law as a special type. It will give a chance to the Soviet jurisprudence to reconcile the Marxist thesis about withering away of the state and law with reality and also to expand it with the theory of socialist law. At the same time, it is ideology that will be the main law formation factor, which will lead Soviet jurisprudence to undervaluation of the objective law formation factors, ideologization and idealization of legal and social norms, nullification of the social content of law, and substitution of "law formation" for the concept "lawmaking".

Dmitriy Kursky, who was the active developer and supporter of the concept of proletarian law, considered that the new communistic law should not protect and recognize individual rights and liberties because it expresses interests of the proletariat. Along with it, he claimed, "The dictatorship of the proletariat can recognize interests of its own class only; the authentic leader of such dictatorship is all the class in general, i.e. workers and the poorest peasants organized in the Communist Party and Councils; an individual, double so a public individual is always an executor, even when he is the most responsible organizer" [11, p. 41]. Emphasizing the fact that the Soviet power had destroyed the bases of the institute of bourgeois law (namely, the old state, the bond family and private property) Dmitriy Kursky deemed it necessary to establish in the
Workers' and Peasants' state a special legal order, under which he meant, as well as other soviet lawyers, limiting and submitting of rights of all social strata to interests of the proletarian dictatorship. The jurist also recognized activities of revolutionary people's courts as a law-making source, claiming that "in their main activity - criminal repression - the national court is absolutely free and is governed first of all by the sense of justice" [11, p. 47].

So why did the sociological direction in jurisprudence get official recognition of the country's leaders in the first years of the Soviet power? On the one hand, this is due to the fact that sociologism of Marxist jurisprudence is determined by historical materialistic postulates of the Marxist doctrine of society, law and state [35, p. 295] On the other hand, if the state and law are destined to die in the very near future, then it is obvious that these social institutes will give place to others, determined by specific features of the new type of society. According to George Hampsch, "As the historical cycle is completed and man once again finds himself living in a classless communist society, the law and state constraint will have withered away. Only morality and social customs will then regulate the relationships of communal life" [28, p. 536]. Meanwhile the greatest interest in these regulators of people' behavior was shown by sociological theory of law via a number of outstanding foreign and Russian pre-revolutionary lawyers. At last, it should be remembered that law of the transition period, in the opinion of the Soviet leaders, had to accomplish one important function among other things, namely educational function. As James Hildebrand notes, "The Soviets acknowledge that their domestic law and legal institutions have an educational role to perform in the molding of the character of the Soviet people. The sociological task of Soviet law is to educate not only the immediate parties to a particular dispute, but also the spectators, the participating public, and society as a whole to be the kind of "new Soviet man" which the socialist state is seeking to develop" [29, pp. 225-226].

\section{Renascence of Sociological Theory of Law}

A distinctive feature of the sociological direction in jurisprudence, which emerged in Europe in the second half of the 19th century, was research into relationships formed in society and 
only formalized by the state. For example, George Gurvich claimed that Leon Duguit "continued and applied to his day researches of theorists who pointed out at existence of the social mechanism of legal regulation as opposed to the state (especially the historical school of lawyers and Pierre-Joseph Proudhon)" [5, p. 659]. We would like to emphasize that the idea of property "socialization" developed in the writings of Leon Duguit was reflected in fundamental laws of Germany $(1919,1949)$ and Japan (1947).

The sociological school of jurisprudence arose and formed as an independent direction of legal consciousness from strong criticism of Legalism. However, in the context of methodology, sociological legal consciousness remained under the positivistic legal tradition, as this area of expertise did not go beyond empirical analysis. Law was considered by them as the fact of social life, but not as a system of regulatory prescriptions of the government. The main task of the sociological direction in jurisprudence, according to its supporters, is to determine how effective legal regulations in a particular society are, i.e. instrumental analysis of law. At the same time, various currently existing concepts of sociological legal consciousness can consider as the basis of law actual rules of conduct developing in social unions, legal precedents, juristically protected order of things, forms of differentiation between social interests, etc. Criticizing the legalistic approach to analyzing legal phenomena and processes, representatives of the sociological direction in jurisprudence do not propose any accurate criteria with the help of which it would be possible to identify which social norms formed as a custom are of the legal nature and can be regarded as a source of law, and which refer to the sphere of morality, religion, some business routines.

In pre-revolutionary Russia, Nicolai Korkunov, Maxim Kovalevsky and Sergei Muromtsev adhered to the sociological type of legal consciousness. According to Nicolai Korkunov, "Jurisprudence should be turned to study law in real life and in progress, but not turn into "the servant of legislation"'. Opposing the identification of law with the statute law, he claimed: "If law and the statute law were identical, then the existence of legal theories would be unclear... If a regulation became legal only due to its taking a form of law, theory of law creation would be the only legal theory" [9, p. 92]. Nicolai Korkunov developed an idea of "subjective realism", as opposed to the extremes of stereotyped individualism, which reduced society to a sum of individuals, and also of the ethical theory of Hegel, dissolving the personality in society and state. $\mathrm{He}$ believed that society represented an objective order, whereas the personality was an "extra independent source" that kept "its self-independence and special purposes that were neither merging with the public ones nor subordinated to them" $[9$, p. 276]. In conformity with such views toward society and the status of an individual in it, the pre-revolutionary lawyer noted that law was necessary for providing order in the event of conflict of interests through their differentiation, i.e. fixation of the limits within which the interest could be implemented (law) and the corresponding limitations in relation to the other interest being in conflict with it (duty).

Unlike moral, law as Nicolai Korkunov believed, did not give a criterion for evaluation of interests in terms of right and wrong, but set limits for implementation of the interests, established certain laws and duties for participants' of social relations. At the same time, he rejected the idea of legal positivism that legal relation was derivative, automatically derived from the legal norm published by the legislator. He also emphasized that subjective law preceded objective in historical sequence. Nicolai Korkunov noted, "Historical evolution always begins with the specific, but not with the general. Therefore, separate subjective laws are created earlier than the general norms regulating them" $[9$, p. 155]. However, after rules of law have developed, they determine subjective laws.

According to another representative of the national pre-revolutionary jurisprudence - Sergei Muromtsev, the term "life of law" is wider than legal norms, "Instead of a set of legal norms, by law is meant a set of legal relations (legal order)" [14, pp. 47-48]. Therefore, definition of law should be based on the legal relationship, but not on a legal norm coming from the state. Moreover, Sergei Muromtsev deemed it necessary for a lawyer, and especially for a judge, to move beyond the formal side of law enforcement, because interpretation of law always assumes its transformation. 
Criticizing dogmatic application of legal norms and considering the reference to the "spirit" of law to be not more than an empty phrase, the scientist tried to bring in the theory of law enforcement such criteria as legal precedents, judicial opinion, social legal consciousness, justice, etc. He noted in the work "What Is Legal Dogma?" (1884), "Expediency of the decision or the norm prompted by creativity is determined by criterion which is based not only on the facts of law, but equally on the facts of economy, morality, religion, etc. ... The less lawyer refers his creative work to the special juridical sphere, i.e. to the sphere of already developed and generally acknowledged legal ideas, the more original and fruitful it is" [15, pp. 31-32].

Thus, representatives of the sociological direction in Russian pre-revolutionary juridical science made attempts to reveal the social nature of law, rejecting legal etatism which understood law as any declaration of the sovereign's will. In addition, their concepts developed within positivism, denying the possibility of cognition of the noumenal essence of law and based on statements that science can only establish empirical connection between phenomena.

Rejecting the idea of "natural law" as the absolute law, eternal and invariable in its essence, supporters of sociological legal consciousness put emphasis on studying legal dynamics, i.e. conditions of origin and development of legal relations preceding norms of state law. They considered law to be a social phenomenon caused by various factors, including historical, socio-economic, political, cultural, psychological, national, etc.

Certainly, it is necessary to recognize obvious merits of the sociological law theory in the development of new methodological approaches to studying the subject of jurisprudence. The sociological conception of law allows one to understand nuances of many-sided and complex social life, to predict the nature of possible changes in social relations, in the way of social life, and to adjust relationship between people, stabilizing the public order. The theory of solidarism underlies the policy of so-called "social collaboration", which was actively introduced by different political forces. Let us notice that in the 1920-30s Soviet jurists (Alexandr Goykhbarg, Jakub Kantorovich, Samuel Asknazy, etc.) tried to apply the theory of social functions developed by Leon Duguit to the legal reality.

Soviet jurisprudence was characterized by theoretical-methodological dogmatism, which eventually led to its crisis and search for new types of legal consciousness in the recent past. However, in 1920-30s there was quite a wide range of various legal concepts. Peter Stuchka called this period the period of "fight for law", "civil war" at the legal front $[19$, p. 5], when theories alternative to the legalistic approach to defining law, its essence, place and role in society are formed. The concept of law as order of social relations proposed by Peter Stuchka, and still drawing attention of foreign lawyers, was formed under the influence of the sociological direction in jurisprudence developed by representatives of pre-revolutionary law. Moreover, as we noted above, this direction of the general theory was closer than others to Marxism.

One of the key provisions of Peter Stuchka's concept is the thesis about identity between functions of the proletarian state and law. In his opinion, they constitute elements of the uniform mechanism of class violence. At the same time, the state is an establishment of organized violence, and law is understood as the corresponding rules, an order of this violence. Thereby, any independent role of law, which completely submits to the state, is denied. Most of the Soviet lawyers (Peter Stuchka's contemporaries) claimed that the state as the political organization of the proletariat and its allies in class struggle had to exist during the transition from capitalism to communism, whereas law was a phenomenon alien to socialism; therefore, it would die off with the bourgeois state. About this period Peter Stuchka will write later, "In our country it was generally accepted to regard law just as a counterrevolutionary, at best anti-revolutionary element, as an anarchy force delaying any revolution" [19, p. 131].

Relying on regulations of Marxist theory about the economy-related law, Peter Stuchka, as well as his colleagues, believed that withering away of law is inevitable. During the proletarian revolution it is completely destroyed, "deposited to the archives of history", because "the proletariat, who had won the power during the October Revolution, broke the bourgeois state apparatus, serving to oppress 
working masses, with all its authorities, army, police, court and church. We hardly need to mention that the same fate came to all codes of bourgeois laws, all the bourgeois law as a system of regulations supporting the balance of interests of social strata for the benefit of bourgeoisie" [19, p. 131].

It is easy to notice signs of legal nihilism in Peter Stuchka's views on law - he denies value of law and raises the question of "cultural revolution" in jurisprudence. Considering that law, in contrast to culture, should not go into the future society, the Soviet lawyer, in fact, leaves it aside culture as something sick and obsolete. However, Peter Stuchka's legal nihilism slightly softened in the course of time. Once it becomes clear that in the near term no withering away of the state and law is expected, he moves away from his radical ideas previously formulated, and considers the necessity to improve Soviet law through codification.

During the period of NEP (1921-1928), Peter Stuchka put forward an idea of limited reception of bourgeois private law, i.e. reception that was within the framework of the socialist state ownership, dictatorship of the proletariat and class interpretation of law. Of course, NEP was a compulsory and temporary measure that had been caused by the deep economic crisis, which had broken out as a result of the Civil War, external intervention and policy of 'War Communism'. Any elements of capitalist economy allowed in planned economy were followed by the active constraint of private commerce and consequent changes in bourgeois law.

The political necessity compels Peter Stuchka, who previously declared fast and complete withering away of law, to begin development of the "proletarian law" concept. The lawyer explains the expediency of developing this sort of law by the necessity to overcome law in principle and move "from law of the socialist building period to nonlaw, to absence and disappearance of any kind of law as unnecessary" [19, pp. 520-521]. In other words, law under socialism remains bourgeois because of immature legal consciousness of public, and it constitutes an institution which thwarts the progress of communism. However, according to Peter Stucka, at that point in time it was impossible to do without law.

From this perspective, he identifies even RSFSR Civil Code of 1922 with bourgeois law and claims that this regulatory legal act is a "the bourgeois code" under the control of "socialist planning of the working class" $[19$, p. 593]. It should be noted that Peter Stuchka was not alone in this view: the idea that law having the bourgeois nature is forced out by the plan as a socialist means, got widespread in Soviet jurisprudence, reflecting ideas of many scholars about the law and socialism essential incompatibility, and also impossibility of juridification of socialism and socialization of law. Like most of his colleagues, Peter Stuchka considered law of the Soviet state mainly bourgeois, and on this basis drew a conclusion that law slowed down building of communism. At the same time, he contradicted himself when admitted the "necessity and peculiarity of Soviet law" provided by the fact it was "proletarian law". He claimed that during the transition period after the proletarian revolution it was impossible to go without the new law, the law which could adopt particular elements of bourgeois legal culture.

Moreover, it was Peter Stuchka who offered the first definition of law in Soviet jurisprudence, which was sociological by character. It received the official consolidation in "The fundamentals of criminal law of the RSFSR", which were intended for national courts. According to this definition, "law is the system (or an order) of public relations corresponding to the interests of the ruling class and protected by its (i.e. this class's) organized force" [18, p. 44]. However, terms used here, such as "system", "order" and "form" were deprived of juridical specificity, which led to the identification of law with production and economic relations. Considering a set of legal norms as a certain aspect of law and claiming that the essence of law consists in legal relations, Peter Stuchka regarded them not as a form of production and exchange relations, but relations themselves, arranged in a special way.

Such definition of law gave a chance to Peter Stuchka's critics to reasonably reproach him for the identification of law with economic relations, and for its dissolution in economics. However, the question of the ratio between law and economics was raised and solved by the scientist at a higher level than his opponents tried to present it. Considering public relations as the basis of law, Peter Stuchka 
noted: “...Not relations themselves are identical with law in general...a number of additional signs are required in order to recognize them as legal". Further he explains that considering the system or order of public relations, he meant “... a certain form of their organization" [20, p. 13].

Moreover, he was accused of sympathies for bourgeois sociologism. Answering the opponents, Peter Stuchka wrote that from the moment the sociological direction emerged in law, “... it was firmly settled that law is exactly the system of social relations" [18, p. 44]. He emphasized the importance "...of the valuable acquisition which was brought by sociological school of bourgeois lawyers ... that law is not just a set of norms ..., but is a system itself, an order of social relations itself" [18, p. 44]. Not denying the influence of Nicolai Korkunov, Sergei Muromtsev and Rodolph Iyering on his concept, the Soviet lawyer noted, "... Of course, it was so, but I borrowed from them only results of their research, but not bourgeois attributes of their science" $[20$, p. 90]. Certainly, such declaration meant that his own concept of law, based on Marxist ideology, still remained within the sociological type of legal consciousness.

Holding a number of important positions among which there was People's Commissar for Justice and Chairman of the RSFSR Supreme Court, Peter Stuchka, paid much attention to revolutionary legality, also defining it from the perspective of sociological jurisprudence. "Revolutionary legality" meant for him a political regime of the proletarian dictatorship in conditions of radical social changes and civil war. On the one hand, it implies limited use of the pre-revolutionary legislation, on the other hand - possible deviation from the Soviet government decrees in the interests of the revolution, and use of the party directives and standards of mass behavior by the court. According to Peter Stuchka, Soviet courts (mostly nonprofessional courts) were supposed to consider cases guided by the principle of political expediency, in the name of the revolution development and with the aim of supporting revolutionary legality.

Within Peter of Stuchka's concept, the coercion proceeding from the ruling class is recognized as the most important sign of law whereby social relations are protected. There are several forms of expression of law: one concrete and two abstrace. The concrete form is not super-structural but basic nature and completely matches economic relations (for example, a right of use, a right of disposition, etc.). The abstract forms of law, which are expressed in regulations and legal ideology, are of the super-structural nature. Thus, legal consciousness and legislation represent a form of law, whereas social relations are its content. Developing this thought, Peter Stuchka noted, "It was to a considerable extent bourgeois legal consciousness that was in disguise of revolutionary or socialist legal consciousness, because any other kind of legal consciousness just did not exist neither in "nature", nor in human consciousness" [20, p. 104]. In primitive society, there was no state and law as means of production were generalized. At the following stages of economic growth (i.e. slave owning system, feudal society) took place a gradual divergence between the abstract and concrete forms; the conflict between the new material relations and the obsolete legislation came as a result of bourgeois revolutions; and due to the proletarian revolution there occurred rapprochement between forms of law based on the material and formal equality, and subsequent integration of these forms under communism. According to Peter Stuchka, it is their integration that would lead to the complete withering away of the state and law.

Throughout his academic career, Peter Stuchka hesitated in solving the problem of what should be understood by law - the "system (order)" of social relations or "the system of norms (laws)" which established, regulated and protected the order of social relations. In the last years of his life, he tended to the interpretation of law as a means of class domination. In his opinion, legal norms were a reflection of material relations prevailing over the legal form. Relying on the idea of class interest, Peter Stuchka claimed that class relations reflecting class interests were primary while legal rules and laws issued by the state were secondary. If social and production relations were basis of law, then in the young Soviet state law was supposed to be given the leading role, expressed in fixing new social relations and assistance in their development. According to the Soviet lawyer, "The one who understood that property, inheritance, act of purchase and sale are nothing more than legal relations, 
and thus are forms of social relations, will understand the social relations which are concealed behind any valid legal article of the law" [20, p. 11]. In this case the law, as it is one of methods of organized mass effect of the state, is necessary only for the period of the state existence.

At the same time, Peter Stuchka rejected the will theory of law, considering it close to idealism. In his opinion, the term "will" has a number of various meanings, and thus it turns into the word either unclear, or causing mess in understanding of the most serious problems [23, p. 505]. On the contrary, according to the scientist, the being determines consciousness and the manifestation of material being is class interest, which is the cornerstone of will, forming the social relations. As he noted in the third volume of "Encyclopedia of State and Law", "To clean the sphere of law off any idealistic remnants, including those of psychological or just contentless phraseological character, will theory of law should be replaced by the interest theory (namely class interest), until a better substitute is found" [21, p. 507]. In fact, here Peter Stuchka agrees with Rodolph Ihering, calling him the most courageous and frank representative of bourgeois legal science, not least because he marked out in law the dominating interest, protected by means of compulsion.

In general, during all his academic career Peter Stuchka was in search for new ways of scientific research. Clearly understanding the imperfection of what had been done by him, he appealed for further creative scientific research. In 1933 Peter Stuchka published the article "My Way and My Mistakes", in which he considered all the way of his scientific research, summed up the results of his work. For instance, he wrote, "It is possible to formulate the concept of law in a more perfect way, of course. Words "system or order" should be more emphasized or replaced by another word which would more clearly indicate the person's conscious participation in the establishment of this "system or order"' [19, p. 58]. As Peter Stuchka admitted, before the article was written he had begun to replace in his researches the term "system" by "a form of organization of social relations", i.e. relations of production and exchange.

Despite strong criticism by representatives of Soviet jurisprudence, the definition of law proposed by Peter Stuchka and his researches should be acknowledge as scientific achievements. His great merit is that he did not reduce law only to norms. Considering it as a complex social phenomenon, Peter Stuchka distinguished particular forms of its expression and implementation, namely legal relations, rules of law and legal consciousness. Moreover, despite all its drawbacks, Peter Stuchka's sociological theory of law had the followers, and it became a source of the ideas based on which the integrative theory, reflecting the new type of legal consciousness, was later formed. Nevertheless, according to Robert Sharlet, "By the late twenties, Pashukanis and his school, supported by the party through the Communist Academy, had come to dominate the intellectual apparatus of the legal culture" [37, p. 161].

Creative development of Soviet jurisprudence was interrupted in 1938, when the definition of law given by Andrei Vyshinsky was acknowledged as the only one true. According to him, law is "a set of rules of conduct expressing the will of the ruling class and established legislatively, and also customs and rules of common living authorized by the government, application of which is provided with the state compulsory force for the purpose of protection, consolidation and development of social relations and orders, profitable and acceptable for the ruling class" [16, p. 37]. Thus, legalistic positivism gained recognition as an official doctrine. However, Andrei Vyshinsky's concept of law came under fire from the Western, first of all American, representatives of jurisprudence. For example, in the article "The Soviet Concept of Law" (1938) Vladimir Gsovsky claimed, "Consequently although now the soviet jurists wish to use the traditional legal concepts, they are still in pursuit of the particular purpose of "class justice" which is not germane to these concepts, and they are not prepared to inscribe on their banner the real supremacy of law and rights. They take the body of traditional jurisprudence but repudiate its soul" [27, p. 43].

Other concepts which made attempts to reconcile the doctrine of Karl Marx and his followers with the Soviet reality were declared harmful and wrong. For this reason, as foreign jurists note, the satisfactory Marxist legal theory could not be created for a long time [36, p. 74; 40, p. $27 ; 41$, p. 357]. For several decades between the legal reality and its researcher there was an impenetrable screen of 
concepts and categories that bore a stamp of the ruling ideology and disfigured ideas of law and its role in people's lives.

\section{Conclusions}

For the long time that jurisprudence has been existing, there has been formed a special language of law, which is, actually, a language of the legal phenomena researcher. The jurist mediates between the legal reality, i.e. social experience, and the subject wishing to comprehend the experience obtained. The emergence of positivism, as well as jus naturalism, which is in the same way not free from legal fetishism (in the former case - formal, in the latter - substantive), was due to the desire to find a benchmark for the intelligent positioning and orientation in the legal reality. Thus, the place of the theological worldview, which used to denote this benchmark on the other side of the real world, primarily occupies metaphysical philosophy of law, handling the concepts of nature and mind, which is then replaced with positivism under the slogan of direct appeal to experience. Renouncing abstract concepts and categories of the "natural law" school, positivists take a function of providing intellectual advance in the legal reality for both an ignoramus and a practicing lawyer. In this regard, worth considering are goals pursued within this function and the ratio between the legal reality and social life. In other words, it should be asked: Does legal positivism explain or excuse phenomena under the proposed legal reality? Is scientific research not replaced with ideology? Is there substitution of notions, as it was in the Soviet Russia, initially in a soft manner and then, after 1938 in a hard and formal manner?

Posing the questions in this form, we find a deterrent on the way of comprehending law which is called by the French expert of Marxist legal theory, Michel Mialle, "legal idealism" [36, p. 49]. Despite dissociation of legal positivism from the jus naturalism, they have a lot in common. Besides the legal fetishism temptation, their representatives opt for ideological abstraction to the disadvantage of scientific, i.e. in favor of representation to the disadvantage of explanation. At first, concepts and categories are only used by them to define new phenomena arising in various spheres of social life ('contract', 'state', 'freedom', 'property', 'inher- itance'); but then those not only acquire an independent meaning, but are explained through other concepts and categories. For example, exchange is regarded not as a fact of social life but as a "contract", the "meeting of partners' minds". Representation of social life proposed by legal science explains and defines itself through concepts and categories, rising ideology up to the level of science and legitimizing emergence of legal norms by reference to the "idea of law". In other words, representation of society posed as the legal reality and meeting demands of particular social groups should not be correct - it should be useful. Not incidentally, the well-known lawyer Sergei Alekseev and foreign lawyers have found similarities between the theory of "natural law" and the Marxist theory of the state and law.

The concept of epistemological deterrent is borrowed from philosophy, where it is used for designation of real and objective deterrents on the way of scientific cognition, which are determined by the social and historical context of a scientist's work. In relation to deterrents on the way of cognition of law, it is necessary to take account of features of the whole complex of institutions under which law is formed, implemented, taught and studied. This material - the "historical continent", in the words of Karl Marx - must be critically comprehended by lawyers in terms of understanding law that is free from legal fetishism and implicates formation of legal science as an essential part of the single "historical continent". As noted by Louis Althusser, "Marx founded a new science: the science of social formations in history or the science of history...Now, when we have determined it, we can say that the history of sciences detects the existence of large specific continents. They are: the Continent of Mathematics (discovered by the ancient Greeks); the Continent of Physical nature (discovered by Galileo); and the largest one - the Continent of History (discovered by Marx)" [22, p. 52]. It might be useful to study the heritage of Soviet political and legal thought for those who travel across the Continent of History.

\section{References}

1. Adoratskiy V.O. O gosudarstve (k voprosu o metode issledovaniya) [On the State (to the Question of Research Method)]. Moscow, 1923.97 p. (In Russ.). 
2. Alekseev S. S. Pravo: azbuka - teoriya-filosofiya. Opyt kompleksnogo issledovaniya [Law: the ABC - Theory - Philosophy. The Experience of Complex Research]. Moscow, 1999. 712 p. (In Russ.).

3. Bukharin N. I. Ekonomika perekhodnogo perioda. Ch. 1. Obshchaya teoriya transformatsionnogo protsessa [Economy of the Transition Period. Part 1. The General Theory of Transformational Process]. Moscow, 1920. $157 \mathrm{p}$. (In Russ.).

4. Goykhbarg A. G. Neskol'ko zamechaniy o prave [Some Observations on the Law]. Sovetskoe pravo - Soviet Law. 1925. Issue 1. Pp. 3-4. (In Russ.).

5. Gurvich G. D. Filosofiya i sotsiologiya prava [Philosophy and Sociology of Law]. St. Petersburg, 2004. 848 p. (In Russ.).

6. Il'inskiy I. Pravo i byt [Law and Everyday Life]. Moscow; Leningrad, 1925. 127 p. (In Russ.).

7. Carbonnier J. Yuridicheskaya sotsiologiya [Sociology of Law]. Moscow, 1986. $352 \mathrm{p}$. (In Russ.).

8. Kozlovskiy M. Yu. Proletarskaya revolyutsiya $i$ ugolovnoe pravo [The Proletarian Revolution and Criminal Law]. Proletarskaya revolyutsiya $i$ pravo - Proletarian Revolution and Law. 1918. Issue 1. Pp. 24-27. (In Russ.).

9. Korkunov N. M. Lektsii po obshchey teorii prava [Lectures on the General Theory of Law]. St. Petersburg, 2003. 430 p. (In Russ.).

10. Krylenko N. V. Besedy o prave $i$ gosudarstve [Discussions about Law and State]. Moscow, 1924. 190 p. (In Russ.).

11. Kurskiy D. I. Izbrannye stat'i i rechi [Selected Papers and Speeches]. Moscow, 1948. 196 p. (In Russ.).

12. Lenin V. I. Polnoe sobranie sochineniy. Izdanie 5-e. [Collected Works]. Moscow, 1962. (In Russ.).

13. Marx K., Engels F. Sochineniya. Izdanie 2-e. [Collected Works]. Moscow, 1955. (In Russ.).

14. Muromtsev S. A. Opredelenie $i$ osnovnoe razdelenie prava [The Definition and Main Division of Law]. Moscow, 1879. 250 p. (In Russ.).

15. Muromtsev S. A. Chto takoe dogma prava? [What is a Legal Thought?]. Moscow, 1885. 35 p. (In Russ.).

16. Osnovnye zadachi nauki sovetskogo prava: materialy 1 Soveshchaniya nauchnykh rabotnikov prava. 16-19 iyulya $1938 \mathrm{~g}$. [The Main Tasks of the Soviet Law Science: Proceedings of the 1st Meeting of Law Researchers. July 16-19, 1938]. Moscow, 1938, 192 p. (In Russ.).

17. Reyusner M. A. Pravo: Nashe pravo. Chuzhoe pravo. Obshchee pravo [Law: Our Law. For- eign Law. Common law]. Leningrad; Moscow, 1925. 276 p. (In Russ.).

18. Stuchka P. I. 13 let bor'by za revolyutsionnomarksistskuyu teoriyu prava: Sbornik statey 1917-1930 [13 Years of the Struggle for the Revolutionary Marxist Theory of Law: Collected Papers of 1917-1930]. Moscow, 1931. 250 p. (In Russ.).

19. Stuchka P. I. Izbrannye proizvedeniya po marksistsko-leninskoy teorii prava [Selected Works on the Marxist-Leninist Theory of Law]. Riga, 1964. 748 p. (In Russ.).

20. Stuchka P. I. Revolyutsionnaya rol' sovetskogo prava [The Revolutionary Role of Soviet Law]. Moscow, 1932. 205 p. (In Russ.).

21. Entsiklopediya gosudarstva i prava: $v 3 t$. [Encyclopedia of State and Law: in 3 vols.]. Moscow, 1925-1927. Vol. 3. 1670 p. (In Russ.).

22. Althusser L. Lénine et la Philosophie Suivi de Marx et Marx et Lénine Devant Hegel. Paris: Ed. François Maspero, 1972. 93 p. (In French).

23. Borella F. Elements de Droit Constitutionnel. Paris: Presses de Sciences Po, 2008. 439 p. (In French).

24. Cohendet M.-A. Droit Constitutionnel. Paris: Montchrestien, 2011. 553 p. (In French).

25. Collins H. Marxism and Law. Oxford: Oxford University Press, 1988. 176 p. (In Eng.).

26. Garapon A. Bien Juger: Essai Sur le Rituel Judiciaire. Paris: Odile Jacob, 1997. 355 p. (In French).

27. Gsovski V. The Soviet Concept of Law. Fordham Law Review. 1938. Vol. 7. Issue 1. Pp. 143. (In Eng.).

28. Hampsch G. H. Marxist Jurisprudence in the Soviet Union: A Preliminary Survey. Notre Dame Law Review. 1960. Vol. 35. Issue 4. Pp. 525-536. (In Eng.).

29. Hildebrand J. L. The Sociology of Soviet Law: The Heuristic and "Parental" Functions. Case Western Reserve Law Review. 1971. Vol. 22. Issue 2. Pp. 157-229. (In Eng.).

30. Hirst P. On Law and Ideology. London: MacMillan Press, 1979. 281 p. (In Eng.).

31. Homan Jr.F. G. Soviet Theory of Jurisprudence. Cleveland State Law Review. 1965. Pp. 402-410. (In Eng.).

32. Kelly J. M. A Short History of Western Legal Theory. New York, 2001. 466 p. (In Eng.).

33. Krygier M. Marxism, Communism, and Rule of Law. Krygier M. (ed.) Marxism and Communism: Posthumous Reflections on Politics, Society, and Law. Amsterdam - Atlanta: Rodopi, 1994. Pp. 137-173. (In Eng.).

34. McLellan D. Karl Marx: His Life and Thought. London: Macmillan, 1974. 498 p. (In Eng.). 
35. Melkevik B. Pasukanis: Une Lecture Marxiste de Maurice Hauriou. Revue D'histoire Des Facultés De Droit Et De La Science Juridique. 1989. No. 8. P. 295. (In French).

36. Miaille $M$. Une Introduction Critique Au Droit. Paris: Ed. François Maspero, 1980. 388 p. (In French).

37. Sharlet R. Stalinism and Soviet Legal Culture. Robert C. Tucker (Ed.). Stalinism: Essays in Historical Interpretation. New York: Norton, 1977. Pp. 155-179. (In Eng.).

38. Terré $F$. Introduction Générale au Droit. Paris: Dalloz, 1998. 646 p. (In French).

39. Villey $M$. Un ouvrage récent sur Marx et le droit, Umberto Cerroni, Marx et il diritto moderno. Archives de philosophie du droit. 1966. XI. Pp. 329-337. (In French).

40. Vincent J.-M. Fétichisme et société. Paris: Anthropos, 1973. 346 p. (In French).

41. Weyl M. et R. La Part du Droit Dans la Réalité et Dans L'action. Paris: Editions sociales, 1969. 384 p. (In French).

42. Zimmermann A. Marxism, Communism and Law: How Marxism led to Lawlessness and Genocide in the Former Soviet Union. The Western Australian Jurist. 2011. Issue 2. Pp. 1-60. (In Eng.).

\section{References in Russian}

1. Адоратский В. О. О государстве (к вопросу о методе исследования). М.: Тип. Моск. Таган. тюрьмы, 1923.97 с.

2. Алексеев С. С. Право: азбука - теория - философия. Опыт комплексного исследования. М.: Статут, 1999. 712 с.

3. Бухарин Н. И. Экономика переходного периода. Ч. 1: Общая теория трансформационного процесса. М.: Гос. соц.-экон. изд-во, 1920. $157 \mathrm{c}$.

4. Гойхбарг А. Г. Несколько замечаний о праве // Советское право. 1924. № 1. С. 3-24.

5. Гурвич Г. Д. Философия и социология права. СПб.: Изд. дом СПбГУ, 2004. 848 с.

6. Ильинский И. Право и быт. М.; Л.: Госиздат, 1925. $127 \mathrm{c}$.

7. Карбонье Ж. Юридическая социология. М.: Прогресс, 1986. 352 с.

8. Козловский М. Ю. Пролетарская революция и уголовное право // Пролет. революция и право. 1918. № 1. С. 24-27.

9. Коркунов Н. М. Лекции по общей теории права. СПб.: Юрид. Центр Пресс, 2003. $430 \mathrm{c}$.

10. Крыленко Н. В. Беседы о праве и государстве. М.: Красная новь, 1924. 190 с.
11. Курский Д. И. Избранные статьи и речи. М.: Юрид. изд-во, 1948. 196 с.

12. Ленин В.И. Полное собрание сочинений. 5-е изд. М.: Гос. изд-во полит. лит., 1962.

13. Маркс K., Энгельс Ф. Сочинения. 2-е изд. М.: Гос. изд-во полит. лит., 1955.

14. Муромиев С. А. Определение и основное разделение права. М.: Тип. А. И. Мамонтова и Ко, 1879. 250 c.

15. Муромиев C. A. Что такое догма права? М.: Тип. А. И. Мамонтова и Ко, 1885.35 с.

16. Основные задачи науки советского права: материалы I Совещания науч. работников права, 16-19 июля 1938 г. М.: Юрид. изд-во НКЮ СССР, 1938. 192 c.

17. Рейснер М. А. Право: Наше право. Чужое право. Общее право. Л.; М.: Госиздат, 1925. $276 \mathrm{c}$.

18. Стучка П. И. 13 лет борьбы за революционно-марксистскую теорию права: сб. ст. 1917-1930. М.: Госюриздат, 1931. 250 с.

19. Стучка П. И. Избранные произведения по марксистско-ленинской теории права. Рига: Латв. гос. изд-во, 1964. 748 с.

20. Стучка П. И. Революционная роль советского права. М.: Сов. законодательство, 1932. $205 \mathrm{c}$.

21. Энщиклопедия государства и права: в 3 т. / В. В. Адоратский, Я. А. Берман, Я. Л. Берман и др.; под ред. П. И. Стучки. М.: Изд-во Комакадемии, 1925-1927. Т. 3. 1670 с.

22. Althusser L. Lénine et la philosophie suivi de Marx et Marx et Lénine devant Hegel. P.: Ed. François Maspero, 1972. $93 \mathrm{p}$.

23. Borella F. Elements de Droit Constitutionnel. Paris: Presses de Sciences Po, 2008. 439 p.

24. Cohendet M.-A. Droit constitutionnel. P.: Montchrestien, 2011. 553 p.

25. Collins H. Marxism and Law. Oxford: Oxford University Press, 1988. $176 \mathrm{p}$.

26. Garapon A. Bien juger: Essai sur le rituel judiciaire. Paris: Odile Jacob, 1997. 355 p.

27. Gsovski V. The Soviet Concept of Law // Fordham Law Review. 1938. Vol. 7. Issue 1. P. 1-43.

28. Hampsch G. H. Marxist Jurisprudence in the Soviet Union: A Preliminary Survey // Notre Dame Law Review. 1960. Vol. 35. Issue 4. P. 525-536.

29. Hildebrand J. L. The Sociology of Soviet Law: The Heuristic and "Parental" Functions // Case Western Reserve Law Review. 1971. Vol. 22. Issue 2. P. 157-229.

30. Hirst P. On law and ideology. London: MacMillan Press, 1979. 281 p. 
31. Homan Jr. F. G. Soviet Theory of Jurisprudence // Cleveland State Law Review. 1965. P. 402-410.

32. Kelly J. M. A Short History of Western Legal Theory. N. Y., 2001. 466 p.

33. Krygier M. Marxism, Communism, and Rule of Law // Marxism and Communism: Posthumous Reflections on Politics, Society, and Law / Krygier M. (ed.). Amsterdam - Atlanta: Rodopi, 1994. P. 137-173.

34. McLellan D. Karl Marx: His Life and Thought. London: Macmillan, 1974. 498 p.

35. Melkevik B. Pasukanis: Une Lecture Marxiste de Maurice Hauriou // Revue D'histoire Des Facultés De Droit Et De La Science Juridique. 1989. № 8. P. 295.

36. Miaille $M$. Une Introduction Critique Au Droit. P.: Ed. François Maspero, 1980. 388 p.
37. Sharlet $R$. Stalinism and Soviet Legal Culture // Robert C. Tucker (Ed.). Stalinism: Essays in Historical Interpretation. N. Y.: Norton, 1977. P. $155-179$.

38. Terré $F$. Introduction générale au droit. P.: Dalloz, 1998. $646 \mathrm{p}$.

39. Villey M. Un ouvrage récent sur Marx et le droit, Umberto Cerroni, Marx et il diritto moderno // Archives de philosophie du droit. 1966. XI. P. 329-337.

40. Vincent J.-M. Fétichisme et société. P.: Anthropos, $1973.346 \mathrm{p}$.

41. Weyl M. et $R$. La part du droit dans la réalité et dans l'action. P.: Editions sociales, 1969. 384 p.

42. Zimmermann A. Marxism, Communism and Law: How Marxism led to Lawlessness and Genocide in the Former Soviet Union // The Western Australian Jurist. 2011. Issue 2. P. 1-60. 